\title{
ADAPTATION OF THE SOCIAL LEGISLATION OF UKRAINE TO THE EU LEGISLATION: THE ISSUE OF REGULATORY AND ORGANIZATIONAL SUPPORT
}

\author{
Maliuha L. Yu.
}

\section{INTRODUCTION}

On February 7, 2019, amendments were made to the Constitution of Ukraine regarding the strategic course of the government to receive full-fledged membership of Ukraine in the European Union and in the North Atlantic Treaty Organization ${ }^{1}$. This is a landmark decision for Ukraine which is primarily aimed at changes concerning the whole state of Ukraine, European identity, the desire of Ukrainian people to be self-sufficient among Europeans. Ukraine has sufficient political and legal prerequisites for the complete integration into the European Union. The right to integration in the EU to Ukraine is enshrined in Article 49 of the Treaty on European Union, determining that any European nation that respects general principles can apply for membership in the Union. Ukraine's membership in Western civilization is also reflected in the Association Agreement with its recognition of European aspirations and Ukraine's European choice.

The peculiarity of the European community, to which Ukraine aspires to belong, is that for European countries among fundamental axiological determinants are human rights and their protection, the value of human life and health, as well as the conscious need to meet socio-economic needs. At the same time, among principal conditions for the European integration of Ukraine are still achieving an adequate level of convergence and consistency of Ukrainian legislation with the legal system of the European Union, ensuring human rights, and adaptation of Ukraine's social policy to the standards of the European Union, etc. As early as 1994, Ukraine has assumed a unilateral obligation implement measures to ensure that its legislation is gradually harmonized with the EU legislation.

The relevance of the current research topic is predetermined by the course of European integration chosen by Ukraine, resulting in active reforms that have been carried out in the social sphere. Accordingly, changes are made to the current domestic legislation in order to ensure decent living conditions for the

\footnotetext{
1 Про внесення змін до Конституції України (щодо стратегічного курсу держави на набуття повноправного членства України в Європейському Союзі та в Організації Північноатлантичного договору) : Закон України від 07 лютого 2019 р. № 2680-VIII. Голос Украӥни. 2019. № 34.
} 
citizens. The reform initiative on the modern social protection system in Ukraine was announced by the President at an expanded meeting of the Cabinet of Ministers of Ukraine. In particular, it was emphasized on increase in the efficiency of social policy, among which is deep modernization of the social protection sphere. During the years of independence, since important political and economic changes took place in Ukraine, social reforms that were carried out during a period of weak economic growth, low rate of job creation, poor labor market management and weak legal regulation have adverse effects. In addition, the annexation of the Crimea and the destabilization of the situation in the Donetsk and Lugansk regions, as additional new challenges for national government, made it difficult to obtain public funds for social assistance. In its turn, this caused dissatisfaction of citizens with the social policy of the state. Among the main consequences that have led to an increase in poverty, it is necessary to highlight the enlargement of the candidate pool of those who entitled to receive payments and various types of social services, the inability to finance government programs, a multiple increase in utility tariffs, a reduction in the number of separate guarantees and social benefits for socially unprotected categories and etc.

It should be noted that today the national social protection system falls beneath the best European models, as well as the legal regulation of which requires the achievement of an adequate level of convergence and consistency of Ukrainian legislation with the legal system of the European Union, and in the context of social policy - ensure adequate protection of human rights, appreciation for the positive value of life and health, as well as socio-economic support in a line with the well-recognized European standards. Therefore, the reasons for the in-depth scientific study of the chosen topic are the lack of clear mechanisms for the implementation of social rights by citizens, the low level of responsibility to the population of Ukraine, shortcomings, conflicts and gaps in the current domestic social legislation. Without any doubt, all mentioned above requires thorough scientific analysis and conceptual improvement. In relation to the above, the outlined topic is relevant and requires multidimensional scientific research.

Recently, in the domestic legal science the issue of strengthening the social protection level, reformation and optimization its system has received considerable scientific attention. An important contribution to the comprehensive investigation of the process of formation of the European legal space in Ukraine, fundamental and applied problems of adaptation is carried out by the research team of the Center for the Study of Problems on Adaptation of the Legislation of Ukraine to the EU Legislation of the Taras Shevchenko Kyiv 
National University, namely: O.O. Hubanov ${ }^{2}$, M.H. Kravchenko ${ }^{3}$, O.A. Myzyka-Stefanchuk ${ }^{4}$, O.S. Pronnevych ${ }^{5}$, A.M. Orlean ${ }^{6}$, M.O. Stefanchuk ${ }^{7}$. Certain aspects of the reformation the social protection system in the aspect of European integration were investigated in the papers of V.M. Andriiv, N.B. Bolotina, M.I. Inshin, O.L. Kuchma, L.M. Siniova, S.M. Synchuk, O.V. Tyshchenko, N.M. Khutoryan, M.M. Shumylo, O.M. Yaroshenko et al. Doctrinal conclusions developed in investigations made by abovementioned scholars do not lose their relevance today. However, a comprehensive analysis of their research gives reason to argue about the absence of comprehensive scientific studies regarding the adaptation of social legislation to the legislation of EU, taking into account the implementation of European legal standards into the national legislation.

\section{Legal basis for the adaptation of the social legislation of Ukraine to the EU legislation}

The ratified Association Agreement between Ukraine, on the one hand, and the European Union, the European Atomic Energy Community and their member states - on the other (dated June 27, 2014) came into effect from 01.09.2017 . Consequently, in the present circumstances, Ukraine has intensified the process of reformation and adaptation of legislation, which contributes to the economic integration and deepening of political association, thus ensuring the development of social and legal state and bringing the social legislation of Ukraine in line with European standards and requirements.

An analysis of the current legislation suggests that the process of adaptation of national legislation to EU legislation was initiated from the moment of declaration by Ukraine of its independence. In 1995, Ukraine became a member

\footnotetext{
${ }^{2}$ Губанов О.О. Європейські стандарти як шляхи удосконалення діяльності публічних службовців. Журнал східноєвропейського права. 2017. № 47. С. 46-52.

${ }^{3}$ Кравченко М.Г. Механізм адаптації законодавства України до законодавства ЄС у сфері управління побутовими відходами: сучасний стан та напрями вдосконалення. Eurasian Academic Research Journal. 2017. № 9. С. 55-65.

${ }^{4}$ Теорія та практика адаптації законодавства України про банківську діяльність до законодавства Європейського Союзу : монографія / О.А. Музика-Стефанчук та ін. ; за заг. ред. О.А. Музики-Стефанчук. Київ : Самміт-Книга, 2016. 263 с.

${ }^{5}$ Проневич О.С. Імплементація європейських правових стандартів захисту прав людини у поліцейське законодавство України. Ukraina po Rewolucji Godności. Prawa czlowieka - to żsamość narodowa / Uniwersytet Łódzki ; red. T. Lachowski, V. Mazurenko. Łódz - Olsztyn : Bookmarked \& amp; Editing, 2017. S. 103-108.

6 Орлеан А.М. Особливості запровадження та функціонування антикорупційного правосуддя в контексті європейських стандартів. Журнал східноєвропейського права. 2018. № 55. С. 6-13.

${ }^{7}$ Стефанчук М. О. Перспективи адаптації законодавства України до стандартів ЄС у сфері правового регулювання ідентифікації фізичної особи. Юридичний журнал «Право Украӥни». 2017. № 8. С. $173-181$.

${ }_{8}^{8}$ Угода про асоціацію між Україною, 3 однієї сторони, та Європейським Союзом, Європейським співтовариством з атомної енергії і їхніми державами членами, з іншої сторони : Міжнародний документ від 27 червня 2014 р. Офіціийний вісник Украӥни. 2014. № 75. Т. 1. С. 83. Ст. 2125.
} 
of the Council of Europe and assumed obligations to carry out constitutional, judicial reform, the adoption of regulations, among which the most important were the Constitution of Ukraine, the Criminal and Civil Codes. Among the first regulatory acts in which the foundations of the integration processes were formed was the Decree of the President of Ukraine dated June 11, 1998 "On Approval of the Strategy for the Integration of Ukraine into the European Union", which determined the main directions of reformation the legal system of Ukraine $^{9}$. One of the key provisions of the Strategy is the definition of the concept of adaptation of Ukrainian legislation to EU legislation. The need of a clear definition is raised by a number of issues related to the convergence of domestic legal order with the modern European legal system, that will ensure the development of political, entrepreneurial, social, cultural activities of Ukrainian citizens, the economic development of the state within the EU framework and will contribute to the gradual growth of citizens' welfare, harmonizing it to the level that has developed in the EU member states.

After the adoption of the Strategy for the Integration of Ukraine into the EU, implementation begins as a stage of legal adaptation. Thus, the Cabinet of Ministers of Ukraine develops and approves the Concept of Adaptation of the Legislation of Ukraine to the Legislation of the European Union, which stipulates that adaptation is one of the priority areas for Ukraine's integration. Against this backdrop, this document sets goals, stages, and implementation mechanism.

The need to reform national legislation was notoriously stemmed from Ukraine's obligations to the EU, which were enshrined in the Partnership and Cooperation Agreement between Ukraine and the European Community (hereinafter refers to as the PCA), which was ratified by the Verkhovna Rada of Ukraine on November 10, 1994 and entered into force on March 1, 1998. Consequently, Article 71 of the PCA regulated social cooperation. Such cooperation was assumed to be quite large-scale and extended to the sphere of education, preparation and assistance in the development of activities, research, technical assistance, cooperation in social sphere. An analysis of this agreement has shown that its provisions did not explicitly provide for the regulation of the mechanism essential for adaptation of the municipal social legislation to the acquis communautaire. However, this document nevertheless laid the foundations for the cooperation between Ukraine and the Member States on social issues. Although the said Agreement has now become invalid, it has an important historical significance, since it had established two stages of the legislative adaptation. Thereby, at the first stage, there were assumed the development of the legal system in Ukraine and its alignment with the requirements of the Agreement and other international acts and treaties. At the

\footnotetext{
${ }^{9}$ Про затвердження Стратегії інтеграції України до Європейського Союзу. Указ Президента України від 11 червня 1998 p. URL: https://zakon.rada.gov.ua/laws/show/615/98 (дата звернення: 26.02.2019).
} 
same time, at the second stage, it was supposed to make a revision of the current national legislation in the focus areas defined by PCA, with a view to approximate compliance with the EU legislation, as well as to facilitate legal support for the creation of free trade zones between Ukraine and the EU and intensify preparations for the Ukraine's associated membership in the EU.

Among other important documents that consolidate the adaptation process are the Laws of Ukraine "On the Concept of the National Program for Adaptation the Legislation of Ukraine to the Legislation of the European Union" ${ }^{\text {"10 }}$ dated 21.11.2002 and "On the National Program for Adaptation the Legislation of Ukraine to the Legislation of the European Union"11 dated March 18, 2004 which determine the mechanism for Ukraine to achieve compliance with the third Copenhagen and Madrid criteria for membership in the European Union. This mechanism includes the adaptation of legislation, the formation of relevant institutions and other complementary measures necessary for the effective lawmaking and law enforcement activities. Adaptation of Ukrainian legislation to EU legislation is a priority component of the process of integration into the European Union, which in turn is considered to be a key direction of the state's external policy.

Adaptation of the legislation of Ukraine is a uniformly well-planned process that includes several stages. At each stage it is necessary to achieve a certain degree of compliance of the Ukrainian legislation with the legislation of the European Union. In its turn, it reflects the compliance of the national legal system with the acquis communautaire based on the criteria set out by the European Union to States that intend to join this institution. In turn, the acquis communautaire (acquis) can be conceptualized as an EU legal system, that includes (but not limited to) European Union legislation adopted within the European Community, Common Foreign and Security Policy and Justice and Internal Affairs. Traditionally, the sources of the acquis communautaire are divided into primary and secondary. The rules of primary law are contained in the EU's constituent documents, and the secondary law is comprised of regulations, directives, decisions adopted by EU institutions. On this basis, the adaptation of legislation is the process of bringing the laws of Ukraine and other regulatory acts in line with the acquis communautaire.

Over the past few years, for scientists from various branches of law, among the subject of scientific research are the issues regarding the legislative adaptation, implementation issues and various aspects of legal harmonization.

\footnotetext{
10 Про Концепцію Загальнодержавної програми адаптації законодавства України до законодавства Європейського Союзу : Закон України від 21 листопада 2002 р. № 228-IV. Офіційинй вісник України. 2002. № 50. Ст. 2233.

11 Про Загальнодержавну програму адаптації законодавства України до законодавства Свропейського Союзу : Закон України від 18 березня 2004 р. № 1629-IV. Відомості Верховної Ради Украӥни. 2004. № 29. Ст. 367.
} 
There are also kaleidoscopic scientific discussions at conferences, forums and round tables. Analysis of the scientific literature allows us to conclude that there is no single, general concept of these processes developed by legal scholars. In the encyclopedic literature, adaptation is defined as: 1) initial system configuration that affects the conditions of application; 2) "acclimatization" to the new environment in the new conditions (work, life, etc.) ${ }^{12}$. From the legislative perspective, this term can be interpreted as adaptation of legislation to the conditions in which it operates. In other words, legal norms must meet the environment in which they regulate social relations. Therefore, for the formation of Ukraine as a European state, it is important that the European principles and standards are functioning in the state.

Legal thinkers that investigate the issues of adaptation of Ukrainian legislation to the legislation of the European Union primarily operate with the term officially coined in the Concept of the National Program for Adaptation of Ukrainian Law to the Legislation of the European Union of 21.11.2002. According to it, the adaptation of Ukrainian legislation to the legislation of the European Union is the phased adoption (in sense "gradual introduction") and implementation of regulatory legal acts of Ukraine designed in compliance with the European Union legislation. Having studied suggested definition, we can conclude on the following features of this procedure. First of all, adaptation is "step-by-step" process. That is, this procedure includes a number of stages and processes, and is not a definite one-time phenomenon. Secondly, adaptation involves not only the adoption, but also the introduction of legal acts. In other words, adopted laws and regulations should be effectively implemented in public relations. Finally, the third feature is quite obvious and is that the national legislation must necessarily be modernized in accordance with the legislation of the European Union. In this case, we can single out the goal of adaptation, by which we should understand the achievement of compliance of the Ukrainian legal system with the EU legal system, taking into account the criteria set out by the EU for the states that intend to join this institution.

Social changes outlined in the above acts are indicated as one of the priorities in the process of adaptation of Ukrainian legislation to EU legislation. In the domestic legal doctrine, scientists define the adaptation of the social legislation of Ukraine to the EU legislation as follows. It is a process of a long-term and step-by-step coordination, adoption and introduction of new or introduction of changes to the existing acts of national social legislation of Ukraine that regulates the activities of persons in labor relations with the employer and persons who have undergone social risk, as a result of which they lost their health and (or) means of subsistence and cannot provide for themselves or their dependents financially. Thus, this type of legislation shall be developed in

\footnotetext{
${ }^{12}$ Бусел В.Т. Великий тлумачний словник сучасної української мови. Київ - Ірпінь : Перун, 2005. С. 11.
} 
accordance with EU legislation, resulting in the convergence of the domestic system of social legislation to the modern European legal order according to the criteria and standards reflected in the current legislation of the EU and the European Union member countries. Consequently, this criteria and standards are put forward in relation to the States that expressed their intention to join the Union. Also it is equally important that such standards of implementation should be scrupulously observed ${ }^{13}$.

Conducted study allows us to highlight the following peculiar features of the adaptation of the social legislation of Ukraine to the EU legislation: 1) gradual in nature; 2) inherently unifies the features essential for harmonization, adaptation, adoption and introduction the standards of EU legislation into the domestic social legislation; 3 ) the heterogeneity of the structural elements of the adaptation of the social legislation of Ukraine to the EU legislation (organizational, legal, socio-economic and scientific-technical nature), and the relationship between them; 4) priority among other areas of legal reformation in Ukraine; 5) a systematic approach that foresees the establishment of procedures that must be performed and the deadlines for their implementation; 6) dependence on the creation of conditions for its implementation.

Clearly, given that the Article 46 of the Constitution of Ukraine enshrines the right of citizens to social protection, which also encompasses the right to ensure them in case of complete, partial or temporary disability, loss of a breadwinner, unemployment due to circumstances beyond their control, in old age and in other cases provided by the law. All this is an inalienable human right and plays a key role in his / her daily life. Therefore, the State must create all the necessary conditions to ensure it, including the improvement the legal regulation in this area both via adaptation of Ukrainian legislation to EU legislation and improvement the management of all spheres of public life, namely, in the area of social policy and security.

Considering that the adaptation of the social legislation of Ukraine to the EU legislation has been taking place for more than a decade, we believe that during this period a number of European standards have become indispensible parts of the domestic legal system. Specifically, it has been resulted in their diversity, as well as the kaleidoscopic forms of their adaptation. Let us take a look at some. Particularly, today the execution of the Decree of the Cabinet of Ministers of Ukraine "On approval of the action plan to ensure compliance with the provisions of the European Social Charter (revised) for 2015-2019" has continued. The specified legal act provides for the ratification of a number of conventions of the International Labor Organization, as well as the implementation of individual recommendations of the Council of Europe and

\footnotetext{
${ }^{13}$ Малюга Л.Ю. Поняття та сутність адаптації соціального законодавства України до законодавства EC. Eurasian Academic Research Journal. 2018. № 5. C. 35-41.
} 
European Union's directives. In addition, the possibility of the gradual and complete accession of Ukraine to the Charter, as well as its accession to the Additional Protocol to the European Social Charter, which provides for a system of collective complaints, is being considered. In this context, among the important steps of a gradual increase in social standards that Ukraine has already taken are:

- ratification on March 16, 2016 of the International Labor Organization Minimum Standards of Social Security Convention № 102, according to which Ukraine today undertakes to comply with 9 of its 15 sections. The key moment of ratification of Convention № 102 is the Ukraine's obligation in the following areas: medical care, assistance in connection with the illness, unemployment benefit, old-age benefit, benefit in case of injury or occupational disease, family support, assistance in connection with pregnancy and childbirth, disability allowance, benefit for loss of breadwinner;

- the signing of the European Code of Social Security, which is considered to be the benchmark for the European model of social security based on the idea of social justice. On November 10, 2016, a signing ceremony was held at the Palace of Europe, which confirms that Ukrainian government focuses its efforts towards the full adaptation of national social legislation to European standards, defined by the multilateral international instruments of Council of Europe. Nevertheless, in order for this document to become legally binding for Ukraine, it still needs to be ratified. In fact, among the post-Soviet countries only Lithuania, Latvia, Moldova and Estonia have signed this document, and only Estonia has ratified it;

- becoming in 2017 a State Party to the paragraphs 3 and 4 of Art. 12 of the Charter "The Right to Social Security", which provides for the application of milestones for the gradual elevation of the social security system to a higher level. In turn, this provides for an obligation to take measures to conclude relevant bilateral and multilateral agreements necessary for ensuring equality between citizens of the contracting parties in social security rights, namely, the preservation of benefits provided by the legislation on social security, regardless of the movement of socially protected persons to the territory of the contracting parties.

Moreover, in order to implement the Action Plan of the Association Agreement, the Government approved the State Policy Strategy on Healthy and Active Ageing of the Population for the Period up to 2022, which defines priority areas for countering demographic changes and provides for comprehensive measures to support older citizens, their integration into the social development, improvement the quality of life, protecting the rights of older people. In particular, it is planned to develop incentives aimed at prolonging the working life for senior citizens, ensure flexible working hours, 
improve working conditions, modernize the pension system (aimed at ensuring a decent level of pensions), strengthen the targeting of social assistance programs, promote physical activity, increase awareness oriented on healthy ageing, expansion of the institutional network of the stationary type and centers / departments providing various types of geriatric care, access to prevention services for premature aging, etc.

The adaptation process of the social legislation of Ukraine to the EU legislation should be considered from the teleological perspective, namely: achieving in practice the high European social standards, in order to avoid duplication of norms and automatic transfer of those legal acts that, based on socio-economic characteristics, cannot be implemented in social legislation of Ukraine. We are of the opinion that the "integrational" problem of modern Ukrainian legislation, which is now in the process of active transformation, into the European institutions of the welfare state. This is primarily due to the existing contradictions between the declared norms of domestic legislation in the sphere of legal regulation of social relations and the actual mechanisms for their implementation and financing. This is primarily a result of the global crisis and the excessive dependence of social factors on the financial and economic development of the country. From the position of the European Committee of Social Rights, despite the existence of regulations that provide the organizational and legal basis for social protection, the level of guarantees actually provided for the relevant groups of the population is predetermined mainly by the State's economic possibilities, and is mostly unsatisfactory.

\section{Organizational support for the adaptation of legislation to the acquis communautaire in Ukraine}

It is important to note that the organizational support for the adaptation of legislation and the adaptation itself are different types of activities, and therefore their actions (procedures, activities) will also differ from each other. The first type has administrative, and the second one - executive character. It is not a secret that the proper management of the process plays a major role in achieving the desired result of the process itself (in our case, adaptation of the legislation). Therefore, a detailed study of the nature of organizational support of the adaptation of the social legislation of Ukraine to the EU legislation is important for its understanding and further implementation within the national framework. Previously, we examined the ways of implementation of European social standards into the Ukraine's social legislation ${ }^{14}$, as well as the specifics of the

\footnotetext{
${ }^{14}$ Малюга Л.Ю. Європейські соціальні стандарти: сучасний стан та шляхи імплементації у соціальне законодавство України. The Journal of Eastern European Law / Журнал східноєвропейського права. 2018. № 48. С. $70-76$.
} 
adaptation of Ukraine's social legislation to EU legislation ${ }^{15}$. That is, we carried out an analysis of the conceptual foundations of social legislation in the EU countries as a whole.

However, for a more structured and complete understanding of the essence of organizational support for the adaptation of Ukrainian legislation to the EU law, crucially, we consider it necessary to reveal its constituent elements. Thus, legal academics tend to distinguish two main approaches to its definition: according to the way of ensuring (financial, informational, personnel, etc.); and according to the elements involved in this process (organizational structures, procedures, etc.). Within the first approach, the main regulations on adaptation also determine its content in different ways. Thus, a separate section of the Concept of Adaptation of the Legislation of Ukraine to the EU Legislation entitled "Organizational Support for the Adaptation Process of the Legislation" contains three types of provisions: financial; informational and scientific; and personnel. The national program for the adaptation of Ukrainian legislation to EU legislation distinguishes institutional support (which is an element according to the second approach) from the financial, personnel and informational (enshrines their content in various sections). In addition to the institutional aspect, for the implementation of adaptation, it is of utmost importance to have clearly defined procedures and legally regulated relationships. After all, the authorities should know what they shall perform in the framework of the adaptation process and how they should interact with each other to get a common result. Only under this condition the implementation mechanism for implementation can work smoothly and efficiently ${ }^{16}$.

The main components of organizational support for the adaptation of Ukrainian legislation to EU law are institutions (including their synergies) and procedures. Within the framework of fulfilling the obligations of Ukraine in accordance with the PCA and in order to fulfill the tasks of the first stage of adaptation of legislation in accordance with the National Program for Adaptation of Ukrainian Law to EU Legislation, the Ministry of Justice of Ukraine had conducted 35 comparative legal studies on the compliance of Ukrainian legislation with the Community's heritage, which covered all areas of adaptation identified in the PCA. In addition, in 2009-2010 about 70 of more than 100 thousand pages of the regulatory legal heritage of the Community were translated into Ukrainian. Also, intensive activities has begun on the analysis of the consequences of introducing into the legislation of Ukraine the European standards, introducing a mandatory examination of draft laws and subordinate

\footnotetext{
15 Малюга Л.Ю. Специфіка адаптації соціального законодавства України до законодавства ЄС: концептуально-правові основи. The Journal of Eastern European Law / Журнал східноєвропейського права. 2018. № 57. C. 83-90.

16 Бєдова О.А. Сутність організаційного забезпечення адаптації законодавства України до ACQUIS ЄС. Інвестииї: практика та досвід. 2017. № 6. С. 117-120.
} 
regulatory legal acts that are being prepared by the Government with an aim to ensure the compliance with such standards.

It is worth noting that in 2000 the National Council for Adaptation of the Legislation of Ukraine to the Legislation of the European Union, headed by the President of Ukraine, was created. Nevertheless, soon its activities were duplicated by the State Council for European and Euro-Atlantic Integration, established in 2002, which was also headed by the President. Also, in October 2004, the Coordination Council on the Adaptation of the Legislation of Ukraine to the Legislation of the European Union, headed by the Prime Minister, was established. In addition, the Institute of the Ukrainian Commissioner for European and Euro-Atlantic integration was introduced ${ }^{17}$. Both "presidential" bodies were liquidated without any explanations in May 2006 and in November 2005, respectively. Thus, at the moment, the mentioned Coordination Council functions de jure. Until recently, it hold its meetings, although once a year, and not two, as defined in the relevant Regulation on its legal status.

According to the prof. O.S. Pronevych, these public authorities did not provide the expected intensification of adaptation the national law-making activities due to the lack of a clear strategic vision of the goals, priorities and prospects for adaptation, the low institutional capacity of the central executive bodies, under-funding, non-functional activities, insufficient delimitation of competence of the above specialized institutions and de facto lack of authority, inadequate scientific support for adaptive activities, the lack of the required number of Ukrainian translations of acts of European law, etc. The presence of this spectrum of challenges necessitated a revision of approaches to the organization of the adaptation of Ukrainian legislation to the acquis communautaire and the adjustment of the corresponding institutional mechanism (administrative structures and certain legal procedures) ${ }^{18}$.

It is necessary to focus on the fact that during 2014-2016, the national institutional mechanism for the adaptation of legislation has been substantially adjusted. In particular, certain attention is drawn to the Decree № 346 "On the Government Office for European and Euro-Atlantic Integration" adopted by the Cabinet of Ministers of Ukraine. According to this Decree, a separate structural unit of the Secretariat of the Cabinet of Ministers of Ukraine - the Government Office for European and Euro-Atlantic integration - was established. It is assumed that this Decree will become invalid in the future. However, no specific date has been set until today; therefore its provisions still regulate the activities of this governmental authority. Thus, the main tasks of the Government Office

\footnotetext{
17 Питання Уповноваженого України 3 питань європейської і євроатлантичної інтеграції: указ Президента України від 26 листопада 2001 р. № 1146 / ВР України. URL: http://zakon.rada.gov.ua/laws/ show/1146/2001 (дата звернення: 23.02.2019).

18 Проневич О.С. Інституційні засади адаптації законодавства України до acquis communautaire: стан легального закріплення та перспективи вдосконалення. Право і Безпека. 2016. № 3. С. 32-39.
} 
are to ensure activities in the field of European and Euro-Atlantic integration of the Cabinet of Ministers of Ukraine, the Prime Minister of Ukraine and the Vice Prime Minister of Ukraine, whose competence covers the issues of European and Euro-Atlantic integration, specifically, regarding the coordination of executive authorities to design and implement activities related to the European and Euro-Atlantic integration; planning, monitoring and evaluating the effectiveness and efficiency of such tasks; coordination of the activities conducted by executive authorities in the development of legislative drafts and other regulatory acts related to European and Euro-Atlantic integration; improvement of the system and mechanism for coordinating the activities of executive authorities in the field of European and Euro-Atlantic integration. Additionally, by adopting a Decree by the Cabinet of Ministers of Ukraine, the competence of the government and the Ministry of Justice of Ukraine in the field of adaptation of legislation changed. In result, the Cabinet of Ministers of Ukraine as the highest executive body has concentrated in itself the whole range of powers, and the Ministry of Justice of Ukraine was deprived of its status as the authorized central executive body in the field of adaptation of Ukrainian legislation to the legislation of the European Union.

The organizational support for the process of adaptation Ukrainian legislation to EU legislation is now confirmed by a diffused system of bodies. Specifically, among them are: the Verkhovna Rada of Ukraine, the Cabinet of Ministers of Ukraine, the Ministry of Justice of Ukraine, the Ministry of Social Policy of Ukraine and the Coordination Council on the Adaptation of Ukrainian Law to the European Union Law.

The Verkhovna Rada of Ukraine is the only legislative body in Ukraine, which means that it is the only authorized authority aimed to ensure the adoption of laws for the fulfillment of Ukraine's obligations in the field of adaptation of social legislation, as well as to carry out legal expertise of draft laws submitted for compliance with the acquis communautaire. Crucially, the coordination of activities in the field of adaptation of legislation is carried out by the relevant Committee of the Verkhovna Rada of Ukraine on European integration. The tool for the implementation of its powers in the field of adaptation of the social legislation of Ukraine to the acquis communautaire is the legislative activity, namely, the adoption of such acts on social legislation that will comply with the provisions of the acquis communautaire.

The Cabinet of Ministers of Ukraine is the highest body in the system of executive bodies. Therefore, the role of this body is primarily to ensure the implementation of governmental programs to adapt the social legislation of Ukraine to the acquis communautaire. The tool to exercise its powers in the field of adaptation of social legislation of Ukraine to the acquis communautaire is the adoption of sub-legislative regulatory acts providing for the creation of special 
institutions for such activities (Interdepartmental Coordination Council on Adaptation of Ukrainian Law to European Union Legislation etc.), as well as establishment of the procedure for their functioning with the aim of achieving the ultimate aim of adaptation.

According to the current legislation, the Ministry of Justice of Ukraine, is a specially authorized central executive body in the area of adaptation of the legislation of Ukraine to the legislation of the European Union. Therefore, today, this public authority actually ensures the implementation of the policy in the area of adaptation of the social legislation of Ukraine to the acquis communautaire, as well as carries out other functions stipulated by the current legislation. Within its framework, the Department of International Law of the Ministry of Justice of Ukraine, whose tasks include, among other things, the implementation of legal expertise of draft legal acts for compliance with the Constitution, laws and other regulatory legal acts of Ukraine, as well as international treaties of Ukraine, the consent of which is granted by the Verkhovna Rada of Ukraine; ensuring cooperation with international organizations of which Ukraine is a member and the responsibility for fulfilling obligations to which is entrusted to the Ministry; examination of compliance with the Ukraine's obligations in the area of European integration and the law of the European Union departmental regulatory acts, etc. It is logical to conclude that all the above powers also relate to the adaptation of the social legislation of Ukraine to the acquis communautaire. Against this background, at the present moment, the tools for the exercising the powers of the Ministry of Justice of Ukraine in adaptation of the social legislation of Ukraine to the acquis communautaire are legal expertise of acts of social legislation of Ukraine for their compliance with European legislation, as well as cooperation with international organizations in issues of social legislation.

Along with this, on February 7, 2019, amendments were made to the Constitution, which stipulate the President of Ukraine as the guarantor of the strategic course of the state for the acquisition of full membership of Ukraine in the European Union and the North Atlantic Treaty Organization.

The Coordination Council on the Adaptation of the Legislation of Ukraine to the Legislation of the European Union ensures the interaction of state authorities and non-state institutions during the implementation of the National Program for Adaptation of the Legislation of Ukraine to the Legislation of the European Union, and also formulates proposals for the development of cooperation with the European Union in the area of social legislation adaptation. In fact, all its functions derive from the name of this body - it coordinates the adaptation of the social legislation of Ukraine to the acquis communautaire. All the instruments for the implementation of the Council's authority in this area are also linked to the coordination - the creation of consulting and expert 
commissions, working groups; obtaining information, documents and materials; analytical activities based on such information, etc.

In accordance with the relevant Regulation, the Ministry of Social Policy of Ukraine is the central executive body that provides the formation and implements the state policy in the social sphere. Part 4 of the Provision stipulates the competence of this public authority includes participation in the implementation of measures essential for the adaptation of the legislation of Ukraine to EU legislation within the limits of authority determined by law. However, in comparison with the previously outlined bodies, such powers are mostly advisory. This body participates, but does not directly adapt the social legislation of Ukraine to the acquis communautaire. That is, the tool for the implementation of its powers in the sphere of adaptation of the social legislation of Ukraine to the acquis communautaire is a consultative participation, which, incidentally, is not the crucial for this mechanism.

It is significant to note that since the entry into force of the PCA, several joint bodies were established in order to facilitate the coordination in the sphere of legislative adaptation. Among such bodies, namely, are:

- The Council on cooperation between Ukraine and the EU as the supreme body that oversees the implementation of the Agreement; it is authorized to take any measures that it considers necessary to achieve the overall aim of the Agreement (paragraph 1 of Article 102 of the PCA prescribes that parties independently take any measures necessary to fulfill their obligations under the Agreement, and make efforts to achieve the objectives defined by the Agreement). In accordance with the Decree of the President of Ukraine dated February 24, 1998 № 148, the Ukrainian part of the Cooperation Council was formed;

- The Committee on Cooperation between Ukraine and the EU established to assist the Council on Cooperation in carrying out its duties. In accordance with the Decree of the President of Ukraine of February 24, 1998 № 148, the Ukrainian part of the Committee was created as a permanent subsidiary body of the Ukrainian part of the Council; It functions as a consultative and advisory body as a Public Expert Council;

- The Committee on Parliamentary Cooperation between Ukraine and the EU, which was established as a forum for political and other dialogue between members of the Verkhovna Rada of Ukraine and the European Parliament.

Ukraine is not the first country that tries to integrate into the EU. When deciding on the model of institutional support for the adaptation, it is useful to take into account the experience of former and current EU candidate countries. In Central and Eastern Europe, there are two main models of organization of the state apparatus for European integration and adaptation of legislation. In the first model, the process was coordinated by the Ministry of Foreign Affairs (Czech 
Republic, Hungary, Slovakia), while in the second - the Government Office (Estonia, Latvia, Lithuania, Poland) ${ }^{19}$.

\section{CONCLUSIONS}

Thus, in the process of research, it was founded that, in fact, the social legislation of Ukraine was adapted to the acquis communautaire, starting from the first years after Ukraine had declared its independence. For Ukraine, there has been shift towards a course on European integration, which resulted in close cooperation with the European Community. The existing organizational framework for the adaptation of social legislation of Ukraine to the acquis communautaire actually has developed from 2004. By its very nature, it can be defined as a combination of national laws, subordinate legislation, international treaties and agreements between Ukraine and the European Union, as well as state bodies ensuring the functioning of this institution. Therefore, nowadays, all provisions of the social legislation of Ukraine are adopted in accordance with European legislation.

\section{SUMMARY}

Ukraine has sufficient political and legal prerequisites for the complete integration into the European Union. The decision regarding the integrational course was a landmark for Ukraine. It is primarily aimed at changes concerning the whole state of Ukraine, European identity, the desire of Ukrainian people to be self-sufficient among Europeans. Against this background, present research is focused on the issues related to the adaptation of national legislation to the legislation of EU with the special references to the legislative standards in social sphere. To obtain more functional and structural view on the outlined issue, the author's attention is focused on two crucial sub-topics. The first one encompasses doctrinal approaches concerning legal basis for the adaptation of the social legislation of Ukraine to the EU legislation, while the second one primarily oriented on the organizational support for the adaptation of domestic legislation to the acquis communautaire. In the end of the conducted analysis, the author finalized all arguments in favor to the adaptation of the social legislation of Ukraine to the standards and requirements of the acquis communautaire. Particularly, it is concluded that all provisions of the social legislation of Ukraine are adopted in accordance with European legislation.

\footnotetext{
${ }^{19}$ Федонюк С.В. Адміністративна координація та інституційне будівництво в Польщі й інших країнах Центральної та Східної Свропи в аспекті підготовки до вступу в ЄС. Науковий вісник Волинського національного університету ім. Лесі Украӥнки. 2009. № 11. С. 56-67.
} 


\section{REFERENCES}

1. Бєдова О.А. Сутність організаційного забезпечення адаптації законодавства України до ACQUIS ЄC. Інвестиції: практика та досвід. 2017. № 6. С. 117-120.

2. Бусел В.Т. Великий тлумачний словник сучасної української мови. Київ - Ірпінь : Перун, 2005. 1728 с.

3. Губанов О.О. Європейські стандарти як шляхи удосконалення діяльності публічних службовців. Журнал східноєвропейського права. 2017. № 47. С. 46-52.

4. Кравченко М.Г. Механізм адаптації законодавства України до законодавства СС у сфері управління побутовими відходами: сучасний стан та напрями вдосконалення. Eurasian Academic Research Journal. 2017. № 9. С. 55-65.

5. Малюга Л.Ю. Європейські соціальні стандарти: сучасний стан та шляхи імплементації у соціальне законодавство України. The Journal of Eastern European Law / Журнал східноєвропейського права. 2018. № 48. C. $70-76$.

6. Малюга Л.Ю. Поняття та сутність адаптації соціального законодавства України до законодавства ЄC. Eurasian Academic Research Journal. 2018. № 5. C. 35-41.

7. Малюга Л.Ю. Специфіка адаптації соціального законодавства України до законодавства СС: концептуально-правові основи. The Journal of Eastern European Law / Журнал східноєвропейського права. 2018. № 57. C. 83-90.

8. Орлеан А.М. Особливості запровадження та функціонування антикорупційного правосуддя в контексті європейських стандартів. Журнал східноєвропейського права. 2018. № 55. С. 6-13.

9. Питання Уповноваженого України 3 питань європейської i євроатлантичної інтеграції: указ Президента України від 26 листопада 2001 p. № 1146 / BP України. URL: http://zakon.rada.gov.ua/laws/ show/1146/2001 (дата звернення: 23.02.2019).

10. Про внесення змін до Конституції України (щодо стратегічного курсу держави на набуття повноправного членства України в Європейському Союзі та в Організації Північноатлантичного договору) : Закон України від 07 лютого 2019 р. № 2680-VIII. Голос України. 2019. № 34 .

11. Про Загальнодержавну програму адаптації законодавства України до законодавства Європейського Союзу : Закон України від 18 березня 2004 р. № 1629-IV. Відомості Верховної Ради України. 2004. № 29. Ст. 367. 
12. Про затвердження Стратегії інтеграції України до Європейського Союзу. Указ Президента України від 11 червня 1998 p. URL: https://zakon.rada.gov.ua/laws/show/615/98 (дата звернення: 26.02.2019).

13. Про Концепцію Загальнодержавної програми адаптації законодавства України до законодавства Європейського Союзу : Закон України від 21 листопада 2002 р. № 228-IV. Офіиійний вісник Украӥни. 2002. № 50. Ст. 2233.

14. Проневич О.С. Інституційні засади адаптації законодавства України до acquis communautaire: стан легального закріплення та перспективи вдосконалення. Право і Безпека. 2016. № 3. С. 32-39.

15. Проневич О.С. Імплементація європейських правових стандартів захисту прав людини у поліцейське законодавство України. Ukraina po Rewolucji Godności. Prawa człowieka - to żsamość narodowa / Uniwersytet Łódzki ; red. T. Lachowski, V. Mazurenko. Łódz - Olsztyn : Bookmarked \& amp; Editing, 2017. 262 s.

16. Стефанчук М. О. Перспективи адаптації законодавства України до стандартів ЄС у сфері правового регулювання ідентифікації фізичної особи. Юридичний журнал «Право України». 2017. № 8. С. 173-181.

17. Теорія та практика адаптації законодавства України про банківську діяльність до законодавства Свропейського Союзу : монографія / О.А. Музика-Стефанчук та ін. ; за заг. ред. О.А. Музики-Стефанчук. Київ : Самміт-Книга, 2016. 263 с.

18. Угода про асоціацію між Україною, 3 однієї сторони, та Свропейським Союзом, Свропейським співтовариством з атомної енергії $\mathrm{i}$ їхніми державами членами, з іншої сторони : Міжнародний документ від 27 червня 2014 р. Офіиійний вісник Украӥни. 2014. № 75. Т. 1. С. 83. Ст. 2125.

19. Федонюк С.В. Адміністративна координація та інституційне будівництво в Польщі й інших країнах Центральної та Східної Свропи в аспекті підготовки до вступу в ЄС. Науковий вісник Волинського національного університету ім. Лесі Украӥнки. 2009. № 11. С. 56-67.

\section{Information about author: Maliuha L. Yu., $\mathrm{PhD}$ in Law, Senior Research Assistant Law Faculty} Taras Shevchenko National University of Kyiv, 60 , Volodymyrska Street, Kyiv, Ukraine ORCID: https://orcid.org/0000-0002-0523-221X 